\title{
An Investigation into English Foreign Language Learning Anxiety and English Language Performance Test Result: Ethiopian University Students in Focus
}

\section{Minwuyelet Andualem Desta ${ }^{1 *}$}

* Correspondence:

minwuye2008@gmail.com

1. Department of English Language and Literature, Debre Tabor University, Ethiopia

Received: 14 August 2019

Revision: 28 October 2019

Accepted: 13 November 2019

Published online: 20 December 2019

\begin{abstract}
The purpose of this study was to investigate the students' English foreign language learning anxiety and English language performance test result. Thus, the objective of the study was to assess the relationship between students' English foreign language learning anxiety and their English language performance. To attain this objective, a descriptive survey research design was employed. Students' first semester English final examination result was used to explore the relationship between students' English classroom anxiety and their English performance test result. In line with this, foreign language classroom anxiety scale and the students' language performance scores were used to collect data. One hundred and seventy six (176) first year students were involved in the study. Multiple instruments that included questionnaire and document analysis were used to gather data. Both quantitative and qualitative data analysis methods were employed to analyze the data. The findings indicated that most of the students were found to be anxious. Furthermore, the findings showed that there was a significant negative relationship between students' English foreign language learning anxiety and their English performance test result. Also, the findings of the study revealed that anxiety is much more prevalent in line with the subjects of the study and had negative correlations with their English language performance exam result. Finally, it was recommended that EFL instructors should acknowledge anxiety feelings as legitimate and attempt to lesson students' feelings of inadequacy and failure by providing positive experiences and feedback to counter act anxiety.
\end{abstract}

Keywords: anxiety, English foreign language, language performance, test anxiety 


\section{Introduction}

Language learning is undoubtedly viewed as a quite complex and multifaceted process in nature. Over the past few decades, there is a widespread agreement that language researchers aim to explore the reasons rendering language learning process more difficult (Rodriguez \& Abreu, 2003). English foreign language anxiety is a complex issue not just an isolated part of language learning. It can be defined as the feeling of tension and apprehension specifically associated with second language learning contexts, including speaking, listening, and language learning as a whole (Macintyre \& Gardner, 1994). Students of all levels of academic achievement and intellectual abilities are believed to be affected by anxiety in language learning. This anxiety occurs in varying degrees and is characterized by emotional feelings and worry, fear, and apprehension (Cubuku, 2008).

Concerning to McDonald (2001 as cited in Cubuku, 2008), anxiety can be exhibited differently by individuals. As students' progress, abundant pressures and different anxiety levels might affect their language achievement. Research findings (Aida, 1994; Horwitz, 1986; MacIntyre \& Gardner, 1994) had consistently revealed that anxiety can impede foreign language production and achievement. It has been observed that students in English classroom experience anxiety that results in stuttering and feelings of uneasiness.

Language researchers have identified a number of learners' factors which are thought to have a considerable influence on language learning. Anxiety has been regarded as one of the most important affective factors that influence second language learning. Studies by different scholars (Scovel, 1978; Macintyre \& Gardner, 1994), especially in Western countries, have been conducted to investigate the relationship between foreign language learning anxiety and performance in the learning of foreign language at different environments. On the other hand, Chastain (1975) found positive relationship between language anxiety and second language performance.

On one side, there was a study by Horwitz, et al. (1986), and Macintyre and Gardner (1994) which indicated that foreign language anxiety is responsible for students' emotional reaction to language learning. More recently, Erden (2007) and Cubuku (2007) have conducted research on this context to see classroom language anxiety and language performance in the way of language learning. So as to measure the English language classroom anxiety levels, many of the researchers used the English language classroom anxiety scale which was designed by Horwitz and Cope (1986). The English foreign language classroom anxiety scale, as confirmed by Aida (1994), Horwitz (1986), and Rodriguez and Abreu (2003) was found to be highly reliable instrument to measure anxiety level of students.

English language classroom anxiety is totally different from other types of anxieties (Horwitz et al., 1986). Learners may have the feeling of being unable to express their own ideas in English as a foreign language (EFL) classroom where EFL anxiety emerges. Since English language anxiety not only affects students' attitude and language learning but also is considered to have more debilitating effects than facilitating effects, an investigation and detailed analysis of EFL anxiety is necessary and significant.

\subsection{Statement of the Problem}

Language anxiety is a complicated psychological phenomenon related to language learning. It is a subjective feeling of tension, apprehension, nervousness, and worry associated with an arousal of the automatic nervous system (Horwitz,et al. ,1986). It is said to be one of the affective factors which affect the process of learning. In this regard, Scovel (1978), Horwitz et al. (1986), Young (1991), Macintyre and Gardner (1994), and Aida (1994) claim that language courses are anxiety provoking by nature. Horwitz et al. (1986), in their study of English language classroom anxiety, developed EFL classroom anxiety scale and administered it to the subjects of the study and found that the levels of the students' anxiety and their language performance were trouble.

Cubukcu (2007). investigated the extent and direction of the relationship between English language learning anxiety and learners' English language performance in the preparatory school class. He used English language classroom anxiety scale, a mid-semester test, and scales for assessing speaking skills. His findings indicated that most of the students were highly anxious in different kinds of language performance activities such as speaking. And the learners' anxiety scores were significantly associated with their language performance.

Similarly, a research was conducted by Saito and Samimy (2011) on language test anxiety with particular reference to high school students. The main objective of the study was to know the major factors which cause students to be in a state of anxiety when they take language tests. His findings indicated that the large majority of the subjects of the study were found to be poor in their language. As a result, their level of anxiety was high when taking the language 
tests. Also, Ando (2013) investigated a study to see whether learners' educational perception had a bearing on what happened in the classroom. According to his finding, both teachers and students appreciated more interactive learning, though there was a conflict between how they enjoyed learning and how they felt they ought to learn. Therefore, students' expectation and experience of the learning situation might be expected to cause anxiety.

With regard to the English foreign language learning classroom anxiety, local studies focused on Ethiopian secondary schools. For this reason, we cannot find enough studies on foreign language classroom anxiety on the Ethiopian higher institutes/universities. We only find a few studies which were conducted at the tertiary level, particularly at the colleges and universities level (Rachman, 1998 as cited in Na, 2007). And those studies might not reflect the real situations of university students English language way of teaching. Thus, the researcher was interested to check what happens in the Ethiopian higher institutes/universities in line with the students' English foreign language learning anxiety, particularly at social science and natural science students of Debre Tabor University, Ethiopia.

As in any English foreign language learning context, Debre Tabor university first year students may be expected to experience anxiety in English classes due to the fact that English is a foreign language to them and for other reasons such as the classroom conditions, the university situation, and the personalities of EFL instructors and students themselves. It is clear that many factors may contribute to language classroom anxiety. However, this study focused on specific English language classroom anxiety.

It is important to investigate if differences in students' performance in English language can in any way be attributed to their experiencing different levels of anxiety as they learn and use the English language in the EFL teaching and learning way. In Ethiopia, university students who are still at a comparatively low level of English language proficiency, may easily experience a feeling of uneasy, suspense, and anxiety. As a result, the current study tried to find out whether English foreign language learning anxiety and students' English language performance exam result had correlations or not on Debre Tabor university first year students.

\subsection{Research Questions and Hypotheses}

The present study was conducted to answer the following research questions:

$>$ Is there a significant relationship between students' gender and English language anxiety?

$>$ Is there a relationship between students' English language learning anxiety and English language performance test result?

$>$ Is there a correlation between students' exam anxiety and their English language anxiety?

$>$ Is there performance significant difference between males and females?

So as to investigate the above-mentioned research questions empirically, the following hypotheses were made:

$>$ There is no significant relationship between students' gender and English language anxiety.

$>$ There is no relationship between students' English language learning anxiety and English language performance test result.

$>$ There is no correlation between EFL learning anxiety and their English language performance.

$>$ There is no significant performance difference between male and female students.

\section{Literature Review}

\subsection{Theoretical Perspective}

Language anxiety is believed to be in line with the theories of communication apprehension. It is necessary for teachers to identify those groups of students who are anxious in terms of communication (MacIntyre \& Gardner, 1989). It is widely known that language learners go through continuous stages to master the language learning. They experience failures of understanding the words, grammar, communication techniques, and related fields which make them feel uncomfortable, leading to anxiety. With recurrent occurrences of state anxiety, the students tend to link anxiety arousal with the second language (Young, 1999) and, therefore, the student will expect to experience a feeling of anxiety in the context of second language. This becomes a self-fulfilling emotional prophecy in the students' second language learning. 
In an attempt to understand these individual differences with respect to anxiety, three conceptual explanations of this construct are provided. First, anxiety is considered as a transient psychological state, an immediate response to a specific anxiety-provoking stimulus. Secondly, anxiety is conceptualized as a feature of an individual disposition. Thirdly, anxiety arousal is associated with a specific situation. These three interpretations are referred to as 'trait' anxiety, 'state' anxiety, and 'situation-specific' anxiety (Ryan, 2006). In an attempt to gain a deeper understanding of what might be informing language anxiety, it is useful to consider how these three interpretations of anxiety might be operating in the context of language learning. Trait anxiety refers to a stable predisposition to become nervous in a wide range of situations (Spiel Berger, 1983). According to Dornyei (2005), a general predisposition to experience anxiety in a wide range of situations is seen as a personal characteristic of an individual and is considered one of the primary traits of human personality.

\subsection{Foreign Language Anxiety}

Many researchers have presented different definitions of foreign language anxiety (FLA). Clément (1980) defined foreign language anxiety as a complex construct that deals with learners' psychology in terms of their feelings, selfesteem, and self-confidence. Highlighting the unique feature of FLA, Young (1992) defined it as a complicated psychological phenomenon peculiar to language learning. More precisely, MacIntyre and Gardner (1994) defined FLA as the feeling of tension and apprehension specifically associated with second or foreign language contexts, including speaking, listening, and learning, or the worry and negative emotional reaction arousal when learning or using a second or foreign language (MacIntyre, 1999). Similarly, Macintyre and Gardner (2001).defined anxiety as the psychological tension that the learner goes through in performing a learning task. These definitions emerge from the assertion made by Horwitz and Cope (1986) that FLA is "a phenomenon related to but distinguishable from other specific anxieties" (p. 129). Horwitz et al. (1986) were the first to conceptualize FLA as a distinctive type of anxiety particular to foreign language learning. Their theoretical model of FLA plays a significant role in language anxiety research.

\subsection{The Relationship between Foreign Language Anxiety, and English Performance}

In line with this issue, research on foreign language anxiety in relation to performance has generally focused on the larger context of motivation and attitude, limiting the specific role of anxiety. However, since the 1980s, foreign language anxiety research has increasingly been directed at examining the specific anxiety construct, the relationship between anxiety and learner variables, the relationship between anxiety and achievement, and the effects of anxiety on foreign language learner (Horwitz, 1986; Horwitz, Horwitz, \& Cope, 1986; Macintyre, \& Gardner; 1991; Young, $1991 \& 1992)$. Over the past few years, foreign language educators have found that anxiety plays a role in success or failure in foreign language (Ganschow et al., 1994). Similarly researchers indicate that high level of anxiety can interfere with foreign language performance and achievement (Brown, 1994; Dulay et al., 1982; Larsen- Freeman \& Long, 1991; Skehan, 1989).

So as to the negative correlations between EFL classroom anxiety and English language performance, Macintyre and Gardner (1991) pointed out that as experience and proficiency increase, anxiety declines in a fairly consistent manner. On the contrary, foreign language anxiety develops if the students following experiences with the foreign language are not positive. Poor language performance in turn reinforces foreign language anxiety.

\subsection{Foreign Language Anxiety and Gender}

Researchers suggested that differences between female and male participants have been examined in some language anxiety studies. Some research investigations (Bekleyen, 2001; Elkhafaifi, 2005; Pappamihiel, 2001) have suggested female students often have higher levels of anxiety than males in academic settings. In the field of language learning, Von Worde (2003) reported that female students were more likely to be much apprehensive than male learners. In another research, according to Aida (1994), however, no statistically associations between language anxiety in learning Japanese and gender were observed, although mean FLCAS scores were slightly lower for females; males scoring an average of 97.4 on the FLCAS, and females scoring 95.6.

In the same way, Erden (2007) found that no significant difference was seen between anxiety levels of males and females. The purpose of Pappamihiel's (2001) investigation was to examine language anxiety in Mexican adolescent girls, extending other studies that had reported that females more than males suffer from worry and anxiety in various academic stage. However, in study conducted in Chinese high Schools, males were found to be more anxious in English classes than females (Na, 2007). 


\subsection{Sources of EFL Anxiety in Ethiopian Context}

In the Ethiopian context, students EFL anxiety occurred from different sources. For instance, Young (1991) noted that language anxiety may have many sources; some are associated with the learner, including low self-esteem and specious beliefs regarding the learning of language, and some with the teacher. Regarding the sources of English language classroom anxiety in the Ethiopian context, it is possible to mention one of them which is frequently observed. For example, Abate (1996) who conducted a research for his MA Thesis could identify some of the potential sources of anxiety his subjects face. These were: students' poor background which goes with their past experience, students' negative expectations on their speaking proficiency, their writing, and their low self-esteem about the language.

\subsection{Previous Findings}

The concept of anxiety in English language learning has been extensively investigated by different scholars from different countries and at different levels of study. At the secondary school level, Gardner and MacIntyre (1993), for instance, investigated that English language classroom anxiety found to be negatively correlated with students' test, speaking and writing performances. The correlation coefficient was -0.26 for test anxiety, -0.23 for speaking anxiety, and -0.2 for writing anxiety. His finding indicates that debilitating anxiety was responsible for students' low achievement. Similarly, Meles (2011) found that students' writing test result was poor due to the anxiety they experienced during the test. Here, classroom anxiety and achievement are mainly related negatively. If students suffer from anxiety, their performance in classroom practices will be poor and leads them to failure.

A research conducted by Aderaw (2010) about language reading and listening skills test anxiety with particular reference to Unity, and Rift Valley private university colleges' students taking English courses. The purpose of the study was to examine the challenges which cause students to be in a state of anxiety when they take reading and listening skills tests. His findings revealed that the majority of the subjects of the study were found to be poor in their reading and listening skills because of their poor backgrounds of reading and listening activities before they joined university colleges. Accordingly, their level of anxiety was high when taking the reading and listening skills tests.

Tomas (2014) measured the provoking of writing anxiety and the writing self-efficacy in English composition among high school teachers. The findings showed that English writing was identified as anxiety-provoking among ESL learners, which created high writing apprehension. It also proved that there was low self-efficacy among the participants, and this was considered to be one of the factors that generated anxiety in English writing.

Students with high level of anxiety share a number of characteristics. A study conducted by Canagarajah (2002) revealed that university language students share at least one of these characteristics: they are usually older, high achievers, had never visited a foreign country, had not taken high school language courses, had low expectations of their overall average for their current language course, had a negative perception of their scholastic competence, or had a negative perception of their self-worth. Tuck (2016) found that in addition to personal characteristics, social circumstances also play a role in generating language anxiety in an academic context.

\section{Methodology}

\subsection{Design of the Study}

In this study, descriptive survey research design which applies quantitative and qualitative methods of data collection (mixed approach) and analysis was employed because it is applicable to obtain important information about the relationship between English foreign language classroom anxiety and students' English performance. The major purpose of descriptive survey is the description of the state of affairs as it exists at present (Kothari, 2004). According to this scholar, the main characteristics of descriptive survey enable the researchers to come up with what has happened or what is happening (Ibid). And the rationally why mixed approach was employed is that it enables the researcher to see the issue under study both from qualitative and quantitative perspectives. And the nature of the problem and the research objectives invited the researcher to use this research method.

\subsection{Participants}

A research participants are the units of analysis as they are the sources from which research data are being collected (Higson Smith, 2000). Therefore, data analysis should reflect an accurate picture of the research participants. In light of this, the analysis and the general discussion of this study revolved around at the government university students. 
Hence, the subjects of the study were 2019 university first year students. Here, the first semester English final examination was taken as the source of data. Thus, students' English final examination result was used to determine the correlation between students' anxiety level and their performance.

\subsection{Population and Sampling Techniques}

In Ethiopia, particularly in the Amhara National regional state, there are ten universities. From those, Debre Tabor University was selected purposively for its ease of accessibility of information for the researcher. There were forty five departments in the Debre Tabor University in both social science and natural science faculty in this year. The total number of first year students population including EFL instructors in the selected university of both faculty were 3522. Based on this fact, EFL instructors were taken for this study by comprehensive sampling as they are available in the study since a number of instructors who were teaching English are manageable to take the sample as comprehensive.

Regarding students' participation, there were 1524 males and 1977 females, totally 3500 students in the selected university in 61 sections in this year. The reason why the students were included as target population is to explore the students English language classroom anxiety and their English language performance. In a study, the sample size should be selected 10-20\% of the total population (Gay, (2003). Thus, out of the total social science and natural science first year students mentioned before, $20 \%$ that is 176 students ( 88 students per faculty) were selected from all sections equally through Lottery method, as they are in the same class under the same school curriculum. Because each member of the sample had an equal chance of being selected as the study participants.

\subsection{Instruments}

The instruments used to collect data for the study were questionnaire and document analysis. These instruments were selected because of their suitability for gathering important data for the study. Each of these instruments is briefly described below.

\subsubsection{Questionnaire}

The questionnaire helps to collect a great deal of information within the time limit and help to reach large group of research subjects (Kothari, 2004). The questionnaire was the main data gathering tool employed for securing pertinent information for the study. Because it enabled the researcher to collect data from large group of individuals within a short period of time, it is also easy to administer to a number of subjects in one place at a time. In the current study, questionnaire was used as data collection instruments and was designed to collect relevant data from the sample university students. It consists of thirty two items, of which eight items were for communication apprehension, nine items for fear of negative evaluation, and five items for test anxiety.

As for the remaining ten items, they were put in a group which was named anxiety of English classes. For each item, respondents were required to respond with an answer like strongly agree (E), agree (D), undecided (C), disagree (B), and strongly disagree (A). The questionnaire items were developed through adapting items from Ayneabeba (1993) and through taking insights from the objectives of the study and literature. The purpose of students' questionnaire was to see the relation between students' English foreign language class anxiety and their English performance.

\subsubsection{Document Analysis}

As to Kahn (1993), when document analysis is used as descriptive research, current documents and issues are the foci. In the current study, in addition to the information obtained from the respondents with regard to the students' class room anxiety and their English language performance, this instrument was conducted. Thus, this instrument was designed to see whether or not students English language classroom anxiety correlates with their English performance. The students' first semester English final examination result was used to determine the correlation between students' anxiety level and their achievement. The purpose of developing this instrument was to see the documents such as students' mark lists and other relevant documents so as to see the relationship between students English language classroom anxiety and their English language performance with evidences.

\subsection{Data Collection}

In the course of collecting data for the current study, all the necessary procedures were followed. First, the researcher asked permission from the concerned bodies and explained the purpose of the study before conducting those instruments. Accordingly, the questionnaire was distributed for university sample first year students to see the 
relationship between students English foreign language classroom anxiety and their English performance. Finally, in addition to the information obtained from the respondents from the questionnaire with reference to the students EFL learning anxiety and their performance test result, document analysis related to the study was conducted. Here, the students' first semester final examination result (achievement test result) was collected from their document.

\subsection{Data Analysis}

Data analysis requires the researchers to be comfortable with developing categories and making comparisons and contrasts (Kumar, 2006). For the current study, the researcher employed mixed method of data analysis. Thus, responses of close ended items of the questionnaire were analyzed and described quantitatively through using descriptive statistics like percentage and mean values. And the reliability of the instrument was computed using Statistical Package for the Social Sciences (SPSS) version 17.

Secondly t- test was employed to see if there were any significant differences in EFL learning anxiety between male and female students and their performance differences. Also, Pearson's product moment correlation coefficient was used to analyze the correlation between students EFL learning anxiety and their English performance. However, the analysis of the data which were collected using students' documents was analyzed using qualitative method of data analysis through using narrative form in an interpretive manner.

\section{Results}

This section deals with the analysis and discussion of the data collected from subjects to seek answers for the basic research questions raised in the statement of the problem. The primary purpose of this study was to investigate students EFL learning anxiety and their EFL learning performance. Accordingly, 176 first year students responded to the questionnaire as a sample were assumed to be adequate for the analysis. The data collected from all the subjects of the study were analyzed through using percentage, mean values, t-tests, and correlation coefficients.

\subsection{Situations of First Year University Students' Anxiety in EFL Learning}

English language anxiety is a feeling of tension and apprehension specifically associated with EFL learning contexts, including speaking, listening, writing, and language learning as a whole (Gardner, 1994). Students of all levels of intellectual abilities are believed to be affected by anxiety in language learning. In line with this, the sample first year students who were learning basic writing skills were asked to give their genuine responses about the overall situation of their' anxiety in English language classrooms. According to their responses obtained from the questionnaire, all most all first year university students are mostly anxious in English classrooms since all the students came from different language backgrounds and their level of English language proficiency is poor. Here, $85.9 \%$ of the subjects of the study were found to be anxious. From here, it is possible to deduce that students' background of the English language in Ethiopia even at the university level is poor.

Table 1 . Levels of anxiety within variables

\begin{tabular}{lccc}
\hline variables & List of Items & $\%$ & M (X) \\
\hline Overall English class anxiety & 13 & 29.6 & 3.45 \\
Exam anxiety & 8 & 18.2 & 3.06 \\
Fear of evaluation & 12 & 37.3 & 3.33 \\
Apprehension & 11 & 25 & 3.22 \\
\hline
\end{tabular}

N.B $(\%=$ Percent; $M(x)=$ Mean

With regard to the above table (Table 1), the mean score anxiety level for the language learning anxiety variables, overall English class anxiety, exam anxiety, fear of evaluation and apprehension were $\%=13$ (29.6), M=3.45, 8 (18.2), $\mathrm{M}=3.06,12$ (27.3), $\mathrm{M}=3.33,11$ (25), and $\mathrm{M}=3.22$ respectively. This result indicated that since the anxiety level of each kind of language learning classroom anxiety variables is above the mean value 3.00 , the subjects of the study were found to be more anxious. Although all the anxiety variables scores were above the mean value 3.00 , the subjects' 
apprehension and fear of negative evaluation anxiety variables can indicate that the seriousness of the anxiety, even it is stronger for fear of evaluation. This result supports the findings investigated by different researchers.

For instance, Horwitz, et al. (1986) noted that students with average around 3.00 should be considered slightly anxious, while students with average below mean value 3.00 are probably not anxious; students whose average mean value nears four and above are probably fairly anxious. In the same way, Gardner (1993) noted that speaking is anxiety provoking in English language activities. Chan and Wu (2004) also found that most students are particularly anxious when they have to speak an English language in front of their class. Furthermore, Hedge (2000) and Gardner (1988) stated that apprehension and fear of negative evaluation emerge due to negative experience in speaking, that is, of teachers' feedback, their participation in the classroom, and their peers' comments.

As it can be indicated from the above table, the results indicated that students are anxious in all aspects of anxiety variables. This might happen, for instance, according to Chan and Wu (2004), because of poor performance in the previous English exams, unpleasant test experience from either language class or other classes lead students to transplant the unhappy image to the present English exam unconsciously. Fear of evaluation also happens due to peer evaluation, family background, and teachers' feedback. The existence of anxiety should firstly be attributed to the students' English proficiency and achievement which might not be enough to allow them to communicate with others freely, to express themselves adequately in class and answers teacher questions properly push to fear of evaluation, exam anxiety, speaking anxiety, and other classroom anxieties (Na, 2007).

From here, it is possible to deduce that both social science and natural science first year students of Debre Tabor University indeed had the feeling of anxiety in their English classes in the teaching and learning of the English foreign language. And they experienced more fear of evaluation and speaking, listening, and writing apprehension. In the country of Ethiopia, $90 \%$ of the students have seldom opportunities to communicate, write, and listen with English in or outside the classrooms due to their own mother tongue dominance in the area. As far as the researcher's experience is concerned, it was justified that most EFL teachers even at the university level in Ethiopia mostly emphasize grammar activities, while paying less attention to the four macro skills, especially to listening, writing, and speaking skills. The existence of anxiety in English foreign language learning classrooms can be also ascribed to classroom atmospheres (Na, 2007). In most Ethiopian government universities, the instructors play the role of manager or dominant in all aspects of the classroom practice/activities. Consequently, students may lack a free, relaxed environment for English learning and in testing situations. And they may feel of nervous and more anxious.

\subsection{English Language Anxiety and Gender}

Table 2. Males and Females English Classroom Anxiety

\begin{tabular}{lllll}
\hline Variables & List of Items & Sex & $\%$ & M (X) \\
\hline Overall English class anxiety & 13 & Male & 29.6 & 3.45 \\
& & Female & 32.1 & 3.61 \\
Exam Anxiety & 8 & Male & 18.2 & 3.06 \\
& & Female & 26.3 & 3.21 \\
Fear of Evaluation & \multirow{2}{*}{12} & Male & 27.3 & 3.33 \\
& & Female & 28.4 & 3.44 \\
Apprehension & 11 & Male & 25 & 3.22 \\
& & Female & 23.85 & 3.18 \\
\hline
\end{tabular}

N.B $(\%=$ Percent; $M(x)=$ Mean

The data stated in the above table (Table 2) revealed that in terms of either the overall English class anxiety or each specific kind of anxiety, females' mean sores are a little bit higher than that of mean scores of males one. From this point, it is possible to say that female university students were experience more anxiety than male university students. On the contrary, the result which was obtained from the value of the t- test analysis (the t- test analysis stated in Table 3 below) showed that there were no significant differences between first year male and female students when we 
observe the values of variables of anxiety, except that of the overall students apprehension $(-1.375, \mathrm{p}=0.013<0.06)$ which was significant.

As we can suggest from the idea which was stated in the following table (Table 3), the t-test analysis value pointed out that there were no significant difference between male and female students of the university when we see the total sum of significant $\mathrm{t}$ - test value/result (I.e. $\mathrm{t}=-2.457, \mathrm{P}=1.728>0.06$ ) of anxiety variables. It was noted that the $\mathrm{t}$ - test value of overall anxiety of English class, exam anxiety, fear of evaluation, and the overall macro skills, particularly (listening, writing, \& speaking) anxiety were $(-0.164, \mathrm{P}=0.742>0.06),(-0.388, \mathrm{P}=0.542<0.06),(-0.530$, $\mathrm{P}=0.431>0.06)$, and $(-1.375, \mathrm{P}=0.013<0.06)$, respectively. The significant difference between male and female students in line with the stressed macro skills apprehension indicated that there is a significant difference $(-1.375, \mathrm{P}=$ $0.013<0.06)$. For the rest of the anxiety variables, the students didn't show any significant differences.

Table 3. Significance difference between male and female students' anxiety

\begin{tabular}{lll}
\hline variables & t- test value & $\begin{array}{l}\text { Significance of } t-\text { test value } \\
(\mathrm{p}<0.06)\end{array}$ \\
\hline Overall anxiety of English class & -0.164 & 0.742 \\
Exam Anxiety & -0.388 & 0.542 \\
Fear of evaluation & -0.530 & 0.431 \\
Apprehension & -1.375 & 0.013 \\
& Total $=-2.457$ & Total $=1.728$ \\
\hline
\end{tabular}

Though when we compare the analysis of male and female mean score value of the area of the study, the overall extent of the EFL learning anxiety of university female students were much greater than male students. Although the extent of anxiety levels differ a little bit, no significant difference can be observed in the area of the study. In contradicted with this point, $\mathrm{Na}$ (2007) justified that though male students seem much more anxious than female students, when tested by t- test, no significant difference was observed in the study. Even though the result was not the same, it supports the finding of this study. Similarly, possible differences between female and male respondents as regards anxiety levels have been examined in some language learning studies.

Again, Cheng (2002 as cited in Wilson, 2006), conducted that females were significantly more anxious than male students. Despite the fact that the findings of this study revealed that there are no significant differences between female and male students in levels of anxiety. This finding can also be supported by the findings of Wajo (2009), who also looked into possible relationships between anxiety and gender in their participants, but found no statistically significant correlation. Although in the present study there was no statistically significant difference between males and females' anxiety levels, the fact that females exhibited somewhat in higher levels of anxiety is noteworthy. This might be at least partially accounted for the students differing levels anxiety in language learning and achievement.

The results of the correlation analysis stated (Table 3 below) showed that English learning anxiety and English performance were negatively correlated. The correlation coefficient of each specific kind of anxiety variable is presented as: the anxiety of English class $(-0.205, \mathrm{P}=0.002<0.03)$, exam anxiety $(-0.157, \mathrm{P}=0.67>0.03)$, fear of evaluation $(-0.254, \mathrm{P}=0.003<0.03)$, and overall anxiety of English class was $(-0.132, \mathrm{P}=0.007<0.03)$. 


\subsection{The Correlation between Anxiety and EFL Performance}

Table 4. The correlation of Anxiety with English performance

\begin{tabular}{lll}
\hline variables & coefficients & P-value $(<0.03)$ \\
\hline Overall English class anxiety & -0.205 & 0.002 \\
Exam Anxiety & -0.157 & 0.67 \\
Fear of evaluation & -0.254 & 0.003 \\
Apprehension & -0.132 & 0.007 \\
\hline
\end{tabular}

As far as the values of correlation coefficient is concerned, it is possible to conclude that EFL learning anxiety and its performance were negatively correlated and have significance, but not significant difference except students exam anxiety that showed negative; no significant correlation $(-0.157, \mathrm{P}=0.67>0.03)$. All in all, from all anxiety variables, it is possible to deduce that there was a significant and negative correlation between EFL learning anxiety and students' English performance.

The correlation of the overall anxiety of English class and performance revealed that there was a negative correlation between anxiety and performance $(-0.205, \mathrm{P}=0.002<0.03)$. From this value of correlation, one can conclude that anxiety has a negative impact on students' performance. This is because, if the correlation is negative and the significant value is less than the given point value, anxiety has a negative effect on students' result. This finding is supported by Abate (1996), Melesse (2007), Skehan (1989), Chastain (1975), and Horwitz, 1986) and the like. Similarly, the subjects of this study might experience poor background in English classrooms to accomplish tasks and activities.

Moreover, the stated anxiety variables' negatively correlated revealed that greater degree of anxiety appeared in university students particularly at the Debre Tabor University students. According to Gardner (1985) and LarsenFreeman and Long (1991), negative correlation indicated that anxiety impairs students' performance. As correlation revealed prediction, learners levels of anxiety attribute to experience in the English class can help in predicting their performance in the final examination.

\subsection{Students EFL Performance Variations due to Anxiety}

Table 5. Performance and Anxiety Levels

\begin{tabular}{|c|c|c|c|}
\hline$X>3.00 ; Y<30$ & $\mathrm{X}<3.00 ; \mathrm{Y}>30$ & $\mathrm{X}<3.00 ; \mathrm{Y}<30$ & $\mathrm{X}$ greater $>3.00 \mathrm{Y}>30$ \\
\hline 93 students & 27 students & 19 students & 37 students \\
\hline
\end{tabular}

N.B (X=Level, Y= Performance

Concerning the data stated from the above table, the correlation of anxiety and students' English performance revealed that they were correlated negatively. This showed that as anxiety level of students' increases, their academic result decreases. This was confirmed by the analysis of correlation. However, when we separately investigate the anxiety level and learners' performance, some variations were observed. Students with an average mark of exam performance between zero and 30 were considered unsuccessful, students with an average more than 35 and above were considered successful; this category was based on Erden's (2007) grouping of successful and unsuccessful students.

Thus, students who were anxious and their performance $<30(52.8 \%)$ were 93 students. Those students whose anxiety level $>3.00$ and their performance $>30$ were 37. And students whose average anxiety scores less than 3.00 and their achievement $>30$ were 27 . For the rest 19 students, their anxiety level and performance were below the mean score value of 3.00 and exam result was <30. If the level of anxiety was low, the performance was expected to be higher. This revealed that there is the variation of students' performance and anxiety.

In line with this, Sparks (1995) argument was that rather than the effect of affective variables, language ability differences were the problems of most poor foreign language learners. And they also argued that if foreign language 
learners attribute lack of success in foreign language learning simply to motivation or high level of anxiety, then their anxiety level may be high, being their result accomplishment was high. In spite of the fact that their anxiety level is high, due to hard work, they would be successful. From the above result, one can deduce that there will be students' performance variation if there is anxiety.

\subsection{English Language Performance Difference between Male and Female Students}

Table 6. Performance difference between male and female students

\begin{tabular}{lllccc}
\hline Sex & $\%$ & $\mathrm{M}(\mathrm{X})$ & T-value & $\begin{array}{l}\text { Significance } \\
(\mathrm{P}<0.06)\end{array}$ \\
\hline Male & 42.53 & 52.877 & & & \\
& & & 0.457 & 1.728 & \\
Female & 57.47 & 47.123 & & & \\
\hline
\end{tabular}

N.B $(\%=$ Percent; $M(X)=$ Mean

As it can be indicated from the above table, the mean value of English performance exam result for male and female students are 52.877 and 47.123 , respectively. The value of the $t-$ test was also indicated $(0.457, P=1.728>0.06)$. The mean value of students' performance showed that female students were a little bit lower than male students. On the contrary, no significant difference was found between them since the significance value indicated $1.728>$ significance $\mathrm{t}$ - test value (0.06). However, this result is not supported with the findings of Tadele (2003 as cited in Wilson, 2006) that justified female students were more anxious than male students and scored lower result in their own English language class. On the whole, from the findings of the study, no significant performance difference was observed between male and female first year students of Debre Tabor University in general. Here, it is possible to conclude that there were not performance differences between the students at all.

\section{Discussion}

The main purpose of this study was to investigate the relationship between English foreign language learning classroom anxiety and students' English performance exam result. The study further showed that there was a significant negative relationship between students' EFL learning anxiety and English performance test result in the way of teaching and learning. The study also explored that there was exam result performance variation among the subjects of the study with respect to the students' anxiety level. The results from the analysis of data from interview, questionnaire, and observations are discussed in line with some empirical findings.

The first research question was intended to identify the significant relationship between students' gender and English language anxiety. The question was raised to find out who are more anxious, in line with the English language learning. The results statistically obtained through the questionnaire in this regard generally revealed that female students are more anxious than male students $(p<0.06)$. Therefore, the null hypothesis of the study "there is no significant relationship between students' gender and English language anxiety" was rejected. The finding of this study also tends to agree with Horwitz, et al. (1986) noted that male students considered to be slightly anxious. Instead, this result is inconsistent with the findings of the study of Cheng (2002) and Chan and $\mathrm{Wu}(2004)$.

The second research question was proposed to explore the relationship between students' English language learning anxiety and English performance test result. In line with this point, the obtained result showed that as anxiety level of students' increases, their academic result decreases. Thus, the hypothesis "there is no relationship between students' English language learning anxiety and English language performance test result" contradicted with what it is said. Since if the level of anxiety was low, the performance was expected to be higher. This was confirmed by the analysis of correlation. Students with an average mark of exam performance between zero and 30 were considered unsuccessful, students with an average more than 35 and above were considered successful; this result is corporate with Erden (2007) who found out that if students were more anxious, they would be unsuccessful in their academic life. 
The third research question was intended to examine the correlation between students' exam anxiety and their English language performance. This research question was designed to know whether students' English learning anxiety and English performance were negatively or positively correlated. The results statistically revealed that EFL learning anxiety and its performance were negatively correlated $(p<0.03)$. Accordingly, the hypothesis of the study "there is no correlation between EFL learning anxiety and their English language performance" was consistent with what the idea of research question revealed. Since if the correlation is negative and the significant value is less than the given point value, anxiety has a negative effect on students' result. This finding is corporate with the study of Skehan (1989).

The third research questions was intended to determine the performance significant difference between male and female students. With regard to this point, the findings indicated that there is no significant performance difference between male and female students $(p<0.06)$. Therefore, the null hypothesis of the study "there is a significant difference between male and female students" was rejected.

However, the mean value of students' English performance showed that female students were a little bit lower than male students. On the contrary, no significant difference was found between them since the significance value indicated. However, this result is not consistent with the findings of Tadele (2003 as cited in Wilson, 2006) that justified female students were more anxious than male students and scored lower result in their own language class.

\section{Implications of the Study}

This study investigated the English foreign language learning anxiety and English language performance test result; the results of this study indicated that anxiety is much more prevalent in line with the subjects of the study and had negative correlations with their English language performance exam result. In addition, the findings of this study supported previous done studies about language anxiety. This study suggests many implications for researches, teachers, and administrators of the institutions. Teachers should be aware of the fact that language anxiety affects students' performance in foreign language classes and language anxiety exists in foreign language learning process regardless of students' age, sex, ability, and language level. That's why teachers should prepare their lessons and activities taking the affective variables into consideration. Administrators of the institutions should provide teachers with seminars and workshops about foreign language anxiety to have success in education. Teachers can learn useful ideas from workshops in which the study reports give evidence about existence of anxiety that affects students' performance in foreign language class.

\section{Conclusion}

Based on the results and discussions of the findings of the study, it is possible to conclude that that seventy five percent of the subjects of the study were found to be anxious, since their English language classroom anxiety level was higher than the mean value 3.00. The mean value of the anxiety variables for all the subjects of the study was above the mean value 3.00. From here, it is possible to conclude that anxiety plays its role in English language learning of the subjects of the study. Most of the students experienced language learning anxiety in the teaching and learning way. With regard to male and female students anxiety level, female students were found to be a little bit anxious than male students. On the contrary, their anxiety difference was not significant. Hence, from this result we can conclude that there was no significant anxiety level difference between male and female university students. Also, the correlation coefficient result revealed that English language classroom anxiety and students English performance were negatively correlated. Thus, anxiety has a negative impact on language learning, especially anxiety of speaking, fear of evaluation, and English classes in spite of the fact that some students and their English result and anxiety level do not correlate each other. This point indicated that the students with over confidence and those with higher level of anxiety, anxiety might have forced them to work harder and to be successful on their result of the English language learning. Even if female students ' average result on their English exam result was a little bit less than that of male students, no significant performance difference was seen. To sum up, most of the students even at university level were found to be more anxious. Finally, it is recommended that University EFL instructors should acknowledge anxiety feelings as legitimate and attempt to lessen students' feelings of inadequacy, confusion, and failure by providing positive experiences and feedback to counteract anxiety.

\section{References}

Abate, K. (1996). English language classroom anxiety, performance on classroom tasks and tests: A study of some Ethiopian Civil Service College $1^{\text {st }}$ year students. (MA Thesis, unpublished): AAU, Addis Ababa, Ethiopia. 
Aderaw, R. (2010). Social psychology and second language learning: The role of attitudes and motivation. London: Edward Arnold Publishers Ltd.

Aida, Y. (1994). Examination of Horwitz \& Cope's Construct of Foreign Language Anxiety: The case of students of Japanese. Modern Language Journal, 78(2), 155-168. 10. $\quad$ 10.2307/329005 https://www.jstor.org/stable/329005

Ando, L. (2013). Anxiety and the language learner. In J. Arnold (ed.), Affect in language learning (pp. 57-71). Cambridge, United Kingdom: Cambridge University Press.

Ayneabeba A. (1993). The effects of teachers' and learners' educational expectations on innovating within the language learning process. Unpublished MA Thesis, Addis Ababa University, Addis Ababa, Ethiopia.

Bekleyen, N. (2001). An investigation into the role of anxiety in second language learning. https://www.researchgate.net/publication/309479750_An_investigation_into_the_role_of_anxiety_in_secon d_language_learning

Brown, D. (1994). Principles of language learning and teaching ( ${ }^{\text {rd }}$ Ed). Englewood Cliffs, NJ: Prentice Hall Regents.

Canagarajah, S. (2002). Multilingual writers and the academic community: Towards a critical relationship. Journal of English for Academic Purposes, 1(1), 29-44. https://doi.org/10.1016/S1475-1585(02)00007-3

Chan, Y. S. (2004). A measure of second language writing anxiety: Scale development and preliminary validation. Journal of Second Language Writing, 13(4), 313-335. _ https://doi.org/10.1016/j.jslw.2004.07.001

Chastain, R (1975). Affective and ability factors in second language acquisition. Language Learning, 25(1), $153-161$. https://doi.org/10.1111/j.1467-1770.1975.tb00115.x

Cheng, Y. (2002). Factors associated with foreign language writing anxiety. Foreign Language Annals, 35(6), 647656. https://doi.org/10.1111/j.1944-9720.2002.tb01903.x

Cubukcu, F. (2007). Foreign language anxiety. Iranian Journal of Language Studies, 1(2), $133-142$. https://drive.google.com/file/d/1Vg8qwg4f5IS6xkvpQ2O31-PZNdH8KWSy/view

Cubuku, H. (2008). A study on the correlation between self-efficacy and foreign language anxiety. Journal of Theory and Practice in Education, 4(1), 148-158. https://eric.ed.gov/?id=ED502016

Dörnyei, Z. (2005). The psychology of the language learner: Individual differences in second language acquisition. Mahwah, NJ: Lawrence Erlbaum.

Dulay et al. (1982). Language two. Oxford: OUP.

Elkhafaifi, H. (2005). Listening comprehension and anxiety in the Arabic language classroom. Modern Language Journal, 89(2), 206-221. doi :10.1111/j.1540-4781.2005.00275.x

Erden, M. (2007). The relationship between foreign language anxiety and English achievement of Yildiz Technical University School of Foreign Languages Preparatory Students. Journal of Theory and Practice in Education. 3(1), 24-38).

Ganschow et al. (1994). Differences and language performance among high, average and low- anxious college foreign language learners. Modern Language Journal, 78(1), 41-55. doi: 10.2307/329251 https://www.jstor.org/stable/329251

Gardner, R. C. (1985). Social psychology and second language learning: The role of attitudes and motivation. London: Edward Arnold.

Gardner, C. (1988). The socio- educational model of second language learning: Assumptions, findings, and issues. Language Learning, 38(1), 101-126. https://doi.org/10.1111/j.1467-1770.1988.tb00403.x 
Gardner, H. (1993). Frames of mind: The theory of multiple intelligences (10th anniversary ed.). New York, NY: Basic Books.

Gardner, R. C., \& MacIntyre, P. D. (1993). A student contributions to second language learning. Part II: Affective variables. Language Teaching, 26(1), 1-11. doi: https://doi.org/10.1017/S0261444800000045

Gay. M. (2003). Language research in English education. New York: Oxford University Press.

Hedge, T. (2000). Teaching and learning in the language classroom. Oxford: OUP.

Higson, W., \& Smith, T. (2000). Second language identities and research. London: Continuum.

Horwitz, E. (1986). Preliminary evidence for the reliability and validity of a foreign language anxiety scale. TESOL Quarterly 20(3), 559-562. http://dx.doi.org/10.2307/3586302

Horwitz, E. K., Horwitz, M. B., \& Cope, J. (1986). Foreign language classroom anxiety. Modern Language Journal, 70(2), 125-132. doi: 10.2307/327317 https://www.jstor.org/stable/327317

Kahn, S. (1993). The pragmatics of discourse. In M. Mantero (ed.), Identity and second language learning (pp. 1322). USA: Information Age Publishing.

Kothari, C. (2004). Research methodology: Methods and techniques. Second Revised Edition. New Delhi: New Age International Publishers.

Kumar, Y. (2006). Fundamental of research methodology and statistics. New Delhi: New Age International (P) Ltd.

Larsen-Freeman, D., \& Long, M. (1991). An introduction to second language acquisition research. London: Longman.

MacIntyre, P. D., \& Gardner, R. C. (1989). Anxiety and second-language learning: Toward a theoretical clarification. Language Learning, 39(2), 251-275. https://doi.org/10.1111/j.1467-1770.1989.tb00423.x

MacIntyre, P. D., \& Gardner, R. C. (1991). Methods and results in the study of anxiety and language learning: A review of the literature. Language Learning, 41(1), 85-117. http://faculty.cbu.ca/pmacintyre/research_pages/journals/methods_results1991.pdf

MacIntyre, P., \& Gardner. (1994). The subtle effects of language anxiety on cognitive processing in the second language. Language Learning, 44(2), 285-305. https://doi.org/10.1111/j.1467-1770.1994.tb01103.x

Macintyre, P., \& Gardner, R. (2001). Methods and results in the study of anxiety and language learning: A review of literature. Language Learning, 41(1), 85-117. doi: 10.1111/j.1467-1770.1991.tb00677.x

Melese, B. (2007). English language proficiency: Undergraduate requirements. Ambo University Admissions. Retrieved from http://admissions.colostate.edu/international/englishproficiency

Melesse, Z. (2011). An assessment of English language writing test anxiety: The case of two private university college students taking sophomore English writing course. Addis Ababa: AAU. (MA Thesis unpublished).

$\mathrm{Na}$, Z. (2007). A study of high school students' English learning anxiety. Asian EFL Journal: English Language $\begin{array}{lll}\text { Teaching Article, } & 9(3), & 22-34 .\end{array}$ https://www.researchgate.net/publication/283808631_A_Study_of_High_School_Students'_English_Learni $\underline{\text { ng Anxiety }}$

Pappamihiel, E. (2001). Moving from the ESL classroom into the mainstream: An investigation of English language anxiety in Mexican girls. Bilingual Research Journal, 25(1-2), 31-38. doi: 10.1080/15235882.2001.10162783

Saito, Y., \& Samimy, K. K. (2011). Foreign language anxiety and language performance: A study of learning anxiety in beginning, intermediate, and advanced-level college students of Japanese. Foreign Language Annals, 29(2), 239-349. https://doi.org/10.1111/j.1944-9720.1996.tb02330.x 
Rodriguez, M., \& Abreu, O. (2003). The stability of general foreign language classroom anxiety across English and French. The Modern Language Journal, 87(3), 365-374. https://doi.org/10.1111/1540-4781.00195

Ryan, S. (2006). Language learning motivation within the context of globalisation: An L2 self within an imagined global community. Critical Inquiry in Language Studies, 3(1), 23-45. doi: 10.1207/s15427595cils0301_2

Scovel, T. (1978). The effect of affect in foreign language learning: A review of the anxiety research. Language Learning, 28(1), 129-142. https://doi.org/10.1111/j.1467-1770.1978.tb00309.x

Skehan, P. (1989). Individual differences in second language learning. London: Edward Arnold. Sparks, R.L.

Sparks, R. (1995). A strong inference approach to casual factors in foreign language learning: A response to Macintyre. The Modern Language Journal, 79(2), 235-244. https://www.jstor.org/stable/329622

Spiel, B. (1983). Identity theory and social identity theory. Social Psychology Quarterly, 6(2), 14-23. Retrieved from http://www.jstor.org/stable/2595812

Tomas, N. (2014). Anxiety. New York: Oxford University Press.

Tuck, M. (2016). The orientation of learner language use in peer work: Teacher role, learner role, and individual identity. Language Teaching Research, 11(2), 161-188. doi: 10.1177/1362168807074602

Wajo, I. (2009). Learner- centeredness as language education. Cambridge: CUP.

Wilson, J. (2006). Anxiety in learning English as a foreign language: It's association with student variables, with overall proficiency, and with performance on oral test. Departamento de Filologías Inglesa y Alemana, Universidad de Granada. https://hera.ugr.es/tesisugr/16235290.pdf

Worde, V. (2003). An investigation of students' perspectives on foreign language anxiety. Inquiry, 8(1), 1-15. https://files.eric.ed.gov/fulltext/EJ876838.pdf

Young, D. (19991). Creating a low- anxiety classroom environment: What does language anxiety research suggest? The Modern Language Journal, 75(4), 426-435. doi: 10.2307/329492 https://www.jstor.org/stable/329492

Young, D. (1992). Language anxiety from the foreign language specialist perspective: Interview with Krashen, Omeggio, Hadley, Terrell, and Rardin. Foreign Language Annals, 25(2), 157-172. https://doi.org/10.1111/j.1944-9720.1992.tb00524.x

Young, D. (1999). Affect in foreign language and second language learning: A practical guide to creating a lowanxiety classroom atmosphere. Boston: McGraw-Hill College. 


\section{Appendix A: Questionnaire}

The objective of this questionnaire is to gather information and to examine the degree of English learning classroom Anxiety you may experience. Please read each statement below very carefully and indicate your true feelings in English classroom. Since the success of the study highly depends on your honesty in rating these items, you are kindly requested to respond accordingly.

Your co-operation will be greatly appreciated!

Thank you in advance

Code Sex

Grade

\section{Instruction:-}

The following items are helpful to indicate the anxiety level students have in the English class. Select and circle the item that best describes your reaction.

N.B. To answer each item use the following ranking key

A. Strongly disagree, B. Disagree, C. Undecided, D. Agree, E. Strongly agree

1. I never feel quite sure of myself when I am speaking in my English class.
A B
C
D
E

2. I don't worry about making mistakes in English class.
A B
C
$\mathrm{D}$
$\mathrm{E}$

3. I tremble when I know that I'm going to be called on to speak in English class.
A B
$\mathrm{C}$
D E

4. It frightens me when I don't understand what the teacher is saying in the English language.
A B
C D
$\mathrm{E}$

5. It wouldn't bother me at all to take more English classes.
A
$\mathrm{C}$
D E

6. During English class, I find myself thinking about things that have nothing to do with the lesson.
A B
C
D E

7. I keep thinking that the other students are better at English than I am.

8. I am usually at ease during tests in my English class.
A B
C
D E

9. I start to panic when I have to speak without preparation in English class.
A B
C D
$\mathrm{E}$

10. I worry about the consequences of failing my English class.
A B
C D
$\mathrm{E}$

11. I don't understand why some people get so upset over English classes.
A B
C D
$\mathrm{E}$

12. In English class, I can get so nervous when I forget things I know. 

A $\quad$ B $\quad$ C $\quad$ D $\quad$ E

13. It embarrasses me to volunteer answers in my English class.
A B
$\mathrm{C}$
D E

14. I would not be nervous speaking in the foreign language with native speakers.
A B
C D
E

15. I get upset when I don't understand what the teacher is correcting.
A B
C D
E

16. Even if I am well prepared for English class, I feel anxious about it.
A
C
D E

17. I often feel like not going to my English class.
A
C
D E

18. I feel confident when I speak in English class.
A B
C
$\mathrm{D}$
E

19. I am afraid that my English teacher will correct every mistake I make.
A B
$\mathrm{C}$
D E

20. I can feel my heart pounding when I'm going to be asked to speak in English class.
A B
C
D E

21. The more I study for an English test, the more confused I get.

A $B \quad$ C $\quad$ D $\quad$ E

22. I don't feel pressure to prepare very well for English class.

A $\mathrm{B} \quad \mathrm{C} \quad \mathrm{D} \quad \mathrm{E}$

23. I always feel that the other students speak English better than I do.
A B
C D
$\mathrm{E}$

24. I feel very self-conscious about speaking English in front of other students.
A B
C D
$\mathrm{E}$

25. English class moves so quickly that I worry about getting left behind.

A $B \quad$ C $\quad$ D $\quad$ E

26. I feel more tense and nervous in my English class than in my other classes.
A
$\mathrm{C}$
D E

27. I get nervous and confused when I am speaking in my English class.
A B
C D
E

28. When I'm on my way to English class, I feel confident and relaxed.
A B
C D
E

29. I get nervous when I don't understand every word the English teacher says.
A B
C
E

30. I feel overwhelmed by the number of rules I have to learn to speak English. 

A B
C
D
E

31. I am afraid that the other students will laugh at me when I speak English.

A B C D E

32. I would probably feel comfortable around native speakers of English.

A $B \quad$ C $\quad$ D $\quad$ E 